\title{
TRANSFORMATION OF ECONOMIC PROCESSES ON THE BASIS OF DIGITALISATION
}

\author{
Tetiana Stroiko', Ludmila Nazarova², Natalia Danik ${ }^{3}$
}

\begin{abstract}
The main task of our study is to justify the primary directions of transformation of economic processes on the basis of digitalisation. Nowadays, the digitalisation of the economy in the global economic environment is considered a priority model of global innovation development. Institutional factors are particularly important in the conditions of transformation of economic processes on the basis of digitalisation. They form the fundamental parameters of the long-term functioning of economic systems. It is determined that the role of institutional factors in ensuring economic development is multifaceted as they affect its duration and quality. These factors can be divided into formal and informal. We have systematised the influence of formal and informal institutional factors on the transformation of economic processes. It is found that the inability of the Ukrainian institutional system to ensure effective economic development demonstrates the institutional traps. Negative manifestations of this system hinder the positive directions for the transformation of economic processes, modernisation of the economy, and competitiveness. It is justified that the transformation of management economic processes should be based on the implementation of the proposed system of principles, the use of which will identify and solve a set of problems of social development of the region, which meets the challenges of our time. To create an effective system of interaction between corporate and regional participants, it is necessary to link their goals, to harmonise them with the goals of socio-economic development of the region. This is where digitalisation can help. It is determined that in modern conditions, the problems of the digital sector affect the competitiveness of the economy, as the lag in obtaining and processing relevant data, the inability to use digital resources are accompanied by the loss of former market positions. From the standpoint of the theory of asymmetry of international trade, the digital dependence of one country on another leads to an increase in the gap in economic development between these countries. The rapid development of information and computer technologies and the active Internet penetration into all spheres of human life have led to the transformation of economic processes according to the level of digitalisation. The development and dissemination of key technologies underlying the digital economy have a decisive impact on the transformation of globalisation: they directly affect the production of goods and services, human resources, investment in human and physical capital, foreign direct investment, international technology transfer, industrial innovation. In essence, all this directly affects the efficiency of production, performance, competitiveness, and economic growth - from individual market participants to countries, regions, and the world economy as a whole.
\end{abstract}

Key words: digital economy, digitalisation, economic processes, transformation, institutional factors.

JEL Classification: A10, F55, 017

\section{Introduction}

Ensuring balanced economic development based on systemic digitalisation is a priority for each country and the world community. Nowadays, the digitalisation of the economy in the global economic environment is considered a priority model of global innovation development. Institutional factors are particularly important in the conditions of transformation of economic processes on the basis of digitalisation.

They form the fundamental parameters of the longterm functioning of economic systems. The study of the essence, principles of institutional transformations, identification of trends, contradictions, and factors influencing the formation of the institutional

\footnotetext{
Corresponding author:

${ }^{1}$ V.O. Sukhomlynskyi Mykolaiv National University, Ukraine.

E-mail: tanyastroyko@gmail.com

ORCID: https://orcid.org/0000-0002-0044-4651

${ }^{2}$ V.O. Sukhomlynskyi Mykolaiv National University, Ukraine.

E-mail: ludaviva@gmail.com

${ }^{3}$ V.O. Sukhomlynskyi Mykolaiv National University, Ukraine.

E-mail: natasha.danik29@gmail.com
} 
environment, is of key importance to transform the economic system on the basis of digitalisation successfully. We need a special methodology for studying economic processes in a digital economy, and new analytical tools for understanding reality, which are developed in the institutional theory.

\section{Institutional factors as a foundation for the transformation of economic processes on the basis of digitalisation}

Along with material factors, institutionalists consider the spiritual, moral, legal, environmental, and other factors determined in the historical context to be the driving force of the economy. Among the neo-institutionalists who have studied the process of development of institutions in line with the theme of this study, it is worth noting the works by D. North (Douglass C. North, 2005), who is one of the first to identify the problem of the impact of institutions and institutional changes on economic growth and the functioning of the economy as a whole. Institutional theory notes the importance of structural and institutional features of the real economy. Along with the economic human (homo economicus), G. B. Kleiner (Kleiner, 2014) introduces the concept of institutional man in a purely economic sense, but as homo institutius. He notes that for an institutional human, material and financial resources play the role of constraints, and personal assessment of the situation - the role of a criterion, while for an economic human it is completely opposite.

It is determined that the role of institutional factors in ensuring economic development is multifaceted as they affect its duration and quality. These factors can be divided into formal and informal. Formal institutions are the legislative, judicial, and legal systems, including the specification and protection of property rights, public administration, education and science, market infrastructure: credit and financial, insurance, nonprofit, investment institutions etc.

Informal institutional factors include culture, traditions, standards of behaviour of economic entities, the system of basic economic values that determine relations in society, business practices, attitude to work and business, the degree of trust and honesty in society. We systematised the influence of formal and informal institutional factors on the transformation of economic processes (Table 1 and Table 2 ).

Institutional factors in the transformation of economic processes also include such phenomena as building a responsible state, the degree of development of the stock market, the stability of the tax system, reduction of investment, financial, economic risks, increasing the reliability of cooperation, low bureaucratisation, and corruption, etc. Thus, as factors of economic development, the representatives of the institutional direction consider investments not in fixed capital, but in scientific discoveries, inventions, and innovations.

The inability of the Ukrainian institutional system to ensure effective economic development demonstrates the institutional traps. Negative manifestations of this system hinder the positive directions for the transformation of economic processes, modernisation of the economy, and competitiveness.

Table 1

The influence of formal institutional factors on the transformation of economic processes

\begin{tabular}{|l|l|}
\hline \multicolumn{1}{|c|}{ Formal factors } & \multicolumn{1}{|c|}{ Economic processes } \\
\hline Judicial independence & $\begin{array}{l}\text { Private property rights are more fully protected and conditions for } \\
\text { intensive economic growth are provided }\end{array}$ \\
\hline $\begin{array}{l}\text { Building a responsible state, ensuring the effectiveness of public } \\
\text { administration }\end{array}$ & All the necessary conditions for economic growth are being formed \\
\hline Improving legislation and the legal system & $\begin{array}{l}\text { The most effective source of long-term economic growth and } \\
\text { effectiveness of socio-economic policy }\end{array}$ \\
\hline $\begin{array}{l}\text { Specification and protection of property rights, including } \\
\text { enforcing contractual obligations }\end{array}$ & $\begin{array}{l}\text { Positive impact on long-term economic growth, investment, and } \\
\text { efficiency of financial markets }\end{array}$ \\
\hline Effective corporate governance & Forming a system of effective property relations \\
\hline Favourable business climate (environment) & $\begin{array}{l}\text { Private capital inflow into the process industry and innovative } \\
\text { production activities }\end{array}$ \\
\hline Institutional conditions for attracting investments & Increasing the competitiveness of producers \\
\hline $\begin{array}{l}\text { Development of social and economic institutions, including } \\
\text { scientific and educational systems }\end{array}$ & $\begin{array}{l}\text { The basis of long-term scientific and technological progress, growth of } \\
\text { production culture, and labour productivity }\end{array}$ \\
\hline Perfect market infrastructure (competitive market) & Favourable conditions for investment activities \\
\hline $\begin{array}{l}\text { Simplicity, transparency, progressiveness, and stability of the tax } \\
\text { system }\end{array}$ & Increased tax collection; reduction in the share of the shadow economy \\
\hline $\begin{array}{l}\text { Development of financial markets, stable credible institutions, } \\
\text { banking and credit system, the degree of development of the } \\
\text { stock market }\end{array}$ & $\begin{array}{l}\text { Affecting the rate of savings, the choice of technology, increasing the } \\
\text { competitiveness of economic agents; expanding the scope of innovative } \\
\text { activity of entrepreneurs, optimizing inflation }\end{array}$ \\
\hline
\end{tabular}


Table 2

The influence of formal institutional factors on the transformation of economic processes

\begin{tabular}{|l|l|}
\hline \multicolumn{1}{|c|}{ Informal factors } & \multicolumn{1}{|c|}{ Influence on economic growth } \\
\hline Culture, traditions, standards of behaviour of the economic entities & $\begin{array}{l}\text { Influence economic development through worldview, ideological } \\
\text { and religious guidelines, as well as attitudes to work, business, } \\
\text { property, law, legal culture }\end{array}$ \\
\hline National economic mindset & $\begin{array}{l}\text { Forms effective work motivation; increases social responsibility of } \\
\text { the private sector of economy, enhances the entrepreneurial culture }\end{array}$ \\
\hline Responsible attitude to work and business & Strengthening investment activity \\
\hline Favourable institutional expectations & Stable socio-political situation in society \\
\hline Degree of trust and honesty in society & High force of law, reduction of crime \\
\hline Civilised behaviour of households & Strengthening economic and cooperative ties \\
\hline Institute of business ethics & Elimination of oligarchic and other parasitic organisations \\
\hline Business practices & Intensifies entrepreneurial activity \\
\hline Market culture of officials & Low business transaction costs, high level of tax collection \\
\hline Low corruption & There are no obstacles to entrepreneurial activity \\
\hline Low bureaucratisation & High level of domestic demand; income and consumption growth \\
\hline Low poverty rate &
\end{tabular}

\section{Transformation of economic processes in the conditions of digitalisation: regional dimension}

The transformation of economic processes in the regions should take into account the consistent formation of the foundations of the new Ukrainian identity and economic culture, which synthesise modern and traditional national values, ideas, and orientations.
Specific results can be achieved only on the basis of the implementation of systemic principles and principles of harmonisation. Accordingly, the transformation of management economic processes should be based on the implementation of the proposed system of principles, the use of which will identify and solve a set of problems of social development of the region, which meets the challenges of our time (Figure 1).

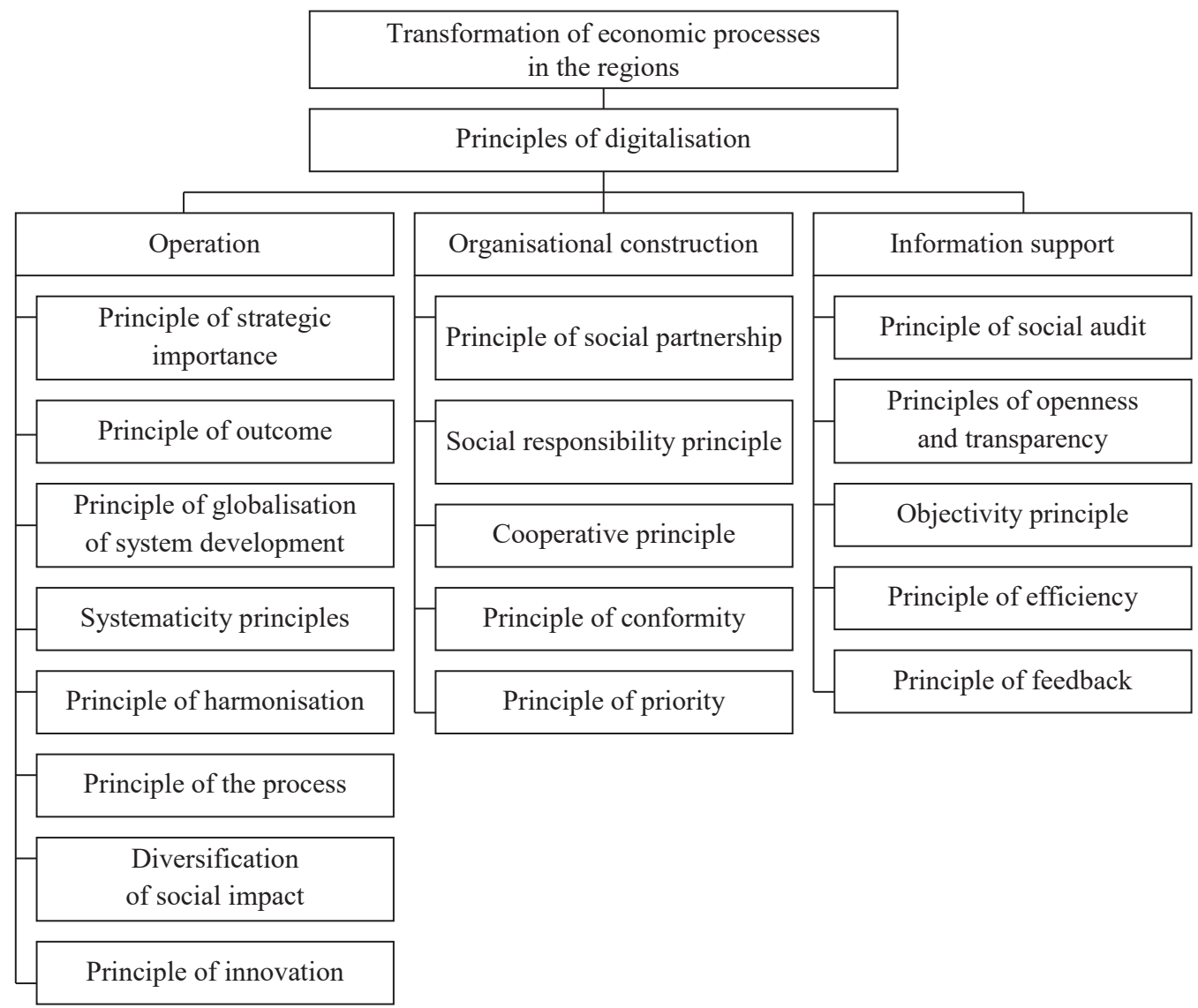

Figure 1. Transformation of economic processes in the regions 
The qualitative characteristics of the entire socioeconomic system of the region depend on the competent organisation of the process of transformation of economic processes. Achieving the goals of socio-economic development in the regions is a complex process determined by the interaction of interests and resources of different groups of stakeholders. The main complexity of socio-economic management in the region is associated primarily with the different nature and scale of corporate participants in different sectors of the regional economy. The isolated actions of these participants cannot ensure comprehensive socio-economic development but often lead to the strengthening the regional disparities. To create an effective system of interaction between corporate and regional participants, it is necessary to link their goals, to harmonise them with the goals of socio-economic development of the region. This is where digitalisation can help.

\section{Digitalisation as an important direction of transformation of economic processes}

In the world's leading countries, the annual investment in the digitalisation of the economy already amounts about one trillion USD a year. By 2020, the economies of the leading countries will spend on digitalisation almost 15 trillion USD (Bukreev, 2018).

The global digital economy is seen as a driving force for economic growth, capable of leading to significant economic changes and affecting the goals of the business, the labour market, and people's way of life; it has significant potential for developing countries, for which such economic shifts can mean economic growth, increased productivity of capital and labour, reduce transaction costs and expand access to world markets (Kovalenko, 2017).

In modern conditions, various aspects of digitalisation of economic processes have been studied by: Jonathan Burston (Jonathan Burston, 2010), Nick Dyer-Witheford (Nick Dyer - Witheford, 2010), Alison Hearn (Alison Hearn, 2010), Christian Fuchs (Christian Fuchs, 2014), Trebor Scholz (Trebor Scholz, 2012), Sevignani (Sevignani, 2013).

It is determined that in modern conditions, the problems of the digital sector affect the competitiveness of the economy, as the lag in obtaining and processing relevant data, the inability to use digital resources are accompanied by the loss of former market positions. From the standpoint of the theory of asymmetry of international trade, the digital dependence of one country on another leads to an increase in the gap in economic development between these countries.

The global digital economy provides companies with new business opportunities:

- unimpeded access to the best suppliers, customers, workforce, financial resources, in whatever country they are located;
- doing business "without borders": real-time interaction with foreign clients and partners, supply chain management on a global scale, supporting the activities of foreign employees in conducting operations and customer service, instant cross-border operations in distant markets;

- reduction of costs for transactions, marketing, interaction with customers in emerging markets;

- organisation of virtual teams through the effective use of digital platforms interacting online;

- transition of small businesses and startups to the category of transnational since its inception.

The rapid development of information and computer technologies and the active Internet penetration into all spheres of human life have led to the transformation of economic processes according to the level of digitalisation.

Digitalisation of the economy requires the development of new business models. Network organisations based on collective methods of production and consumption transform traditional market relations and require the development of new solutions in the field of modern company management. The further development of digital technologies is important for the economy as a whole. Currently, the share of retail trade on the Internet accounts for about $10 \%$ of all transactions; in the future, their number will only increase (Dzhulii, 2015).

Accordingly, digitalisation stimulates the growth of economic value in the field of data creation, transmission, processing, storage. If this kind of activity prevails over activity in the field of agriculture and industry in the economic sphere, then we can talk about the transition to a digital economy. In addition, in such conditions, the data themselves become the object of economic relations. Specialised companies, research organisations provide services for the collection, analysis of data for the purposes of the customer; accordingly, such data have a certain value.

\section{Conclusions}

The development and dissemination of key technologies underlying the digital economy have a decisive impact on the transformation of globalisation: they directly affect the production of goods and services, human resources, investment in human and physical capital, foreign direct investment, international technology transfer, industrial innovation. In essence, all this directly affects the efficiency of production, performance, competitiveness, and economic growth from individual market participants to countries, regions, and the world economy as a whole.

In the context of Ukraine, the presence of many unresolved political and legal issues, outdated economic processes associated with the rapid development of information and communication with 
the advent of digital technologies, has become a sign of danger. Expansion of digital service, individualisation of many types of services have increased the threat of fraud by a wide range of users or providers to a critical level; the risks of information leakage require constant state's attention to increase the level of protection of electronic systems. Accordingly, strategies for the implementation of certain digital technologies should be developed taking into account the needs of the development of the regulatory framework for their implementation and operation, as this includes the processes caused by digitalisation.

\section{References:}

North, Douglass C. (2005). Understanding the Process of Economic Change. Princeton: Princeton University Press. Kleiner, G. B. (2014). The rhythms of evolutionary economics. Voprosy ekonomiki, vol. 4, pp. 123-136.

Bukreev, V. V. (2018). Is digitalisation a panacea for the Russian economy? Voprosy politicheskoi ekonomii, issue 4. Moscow: Kulturnaia revoliutciia.

Kovalenko, B. B., \& Kovalenko, O. H. (2017). Digital globalisation: opportunities and risks of strategic development of business organisations. Hlobalnyi naukovyi potentsial, vol. 10(79), pp. 140-142.

Burston Jonathan, Nick Dyer-Witheford and Alison Hearn, eds. (2010). Digital Labour: Workers, Authors, Citizens. Ephemera: Theory \& Politics in Organization, vol. 10(3).

Scholz T., ed. (2012). Digital Labour. The Internet as Playground and Factory. New York: Routledge.

Fuchs, C. (2014). Theorising and analysing digital labour: From global value chains to modes of production. The Political Economy of Communication, T. 1, no. 2.

Fuchs, C., \& Sevignani, S. (2013). What is digital labour? What is digital work? What's their difference? And why do these questions matter for understanding social media? TripleC: Communication, capitalism \& critique. Open access journal for a global sustainable information society, T. 11, no. 2, pp. 237-293.

Dzhulii, L. V., \& Emchuk, L. V. (2015). Information systems and their role in the activities of modern enterprises. Perspective economic and management issues Collection of scientific articles. Scientific journal "Economics and finance", "East West" Association for Advanced Studies and Higher Education. 